\title{
OPEN Adsorption capability of brewed tea waste in waters containing toxic lead(II), cadmium (II), nickel (II), and zinc(II) heavy metal ions
}

\author{
Hakan Çelebi ${ }^{\bowtie}$, Gülden Gök \& Oğuzhan Gök
}

Recently, the search for low-cost eco-friendly adsorbents has become one of the main objectives of researchers. The aim of this study was to test the removal of four heavy metals, namely lead $(\mathrm{Pb})$, zinc ( $\mathrm{Zn})$, nickel (Ni) and cadmium (Cd), from a simulated watery solution using brewed tea waste as a potentially suitable adsorbent. The effects of $\mathrm{pH}$ levels $(2.0-6.0)$, adsorbent amount $(0.1-5.0 \mathrm{~g})$, contact times (1-150 min.) were examined throughout the adsorption process. The results of the experiments showed that the heavy metals elimination yields had an inverse relationship with $\mathrm{pH}$ and a linear relationship between the other parameters. The optimum $\mathrm{pH}$ for the removal of the heavy metals was between 4.0 and 5.0 in the case of the brewed tea waste. Equilibrium times of 2, 10, 30 and 5 min were required for the adsorption of $\mathrm{Pb}, \mathrm{Zn}, \mathrm{Ni}, \mathrm{Cd}$ onto Camellia sinensis, respectively. Based on the results of this study it can be said that brewed tea waste has a high potential to remove heavy metals from aqueous solutions. The maximum adsorption capacities were calculated as 1.197, $1.457,1.163$ and $2.468 \mathrm{mg} / \mathrm{g}$, for $\mathrm{Pb}, \mathrm{Zn}, \mathrm{Ni}$ and $\mathrm{Cd}$, respectively, by fitting the equilibrium data to the Langmuir isotherm model.

The discharge of heavy metals and other toxic pollutants into waterways is one of the most significant and frequent detrimental effects of industrial activities that causes water pollution ${ }^{1}$. For this reason, many studies focusing on finding a solution to water contamination have been conducted in recent years ${ }^{2-4}$. Zhou, et al. ${ }^{5}$ evaluated data on 12 different heavy metal concentrations in surface waters (168 rivers and 71 lakes) between 1972 and 2017. In addition, they examined the total heavy metal concentrations of rivers and lakes in Asia, Europe and Africa. According to their results, the heavy metal concentrations in rivers in Africa and Asia were 45.04 and $17.75 \mu \mathrm{g} / \mathrm{L}$ for $\mathrm{Cd}, 83.82$ and $92.70 \mu \mathrm{g} / \mathrm{L}$ for $\mathrm{Pb}, 1169$ and $889.57 \mu \mathrm{g} / \mathrm{L}$ for $\mathrm{Zn}$ and, 131.69 and $54.84 \mu \mathrm{g} / \mathrm{L}$ for $\mathrm{Ni}$, respectively. The heavy metal concentrations in European rivers, reached $5.69 \mu \mathrm{g} / \mathrm{L}$ for Cd, $92.70 \mu \mathrm{g} / \mathrm{L}$ for $\mathrm{Pb}, 137.47 \mu \mathrm{g} / \mathrm{L}$ for $\mathrm{Zn}$ and $1338.99 \mu \mathrm{g} / \mathrm{L}$ for $\mathrm{Ni}$. The assessment revealed that over the years' heavy metal contamination had increased in aquatic environments and was at varying concentrations. Metal concentration in natural waters is closely linked with the geology of the region. Mineralized areas in particular have high metal concentrations due to their natural properties. In his study conducted in Turkey, Kacmaz ${ }^{6}$ stated that many streams, springs and deeper ground waters in mineralized regions contained high metal concentrations. In recent years, as a result of the development of important sectors such as agriculture, battery production, metal plating the discharge of heavy metals into the environment has increased both directly and indirectly. Hazardous heavy metals such as $\mathrm{Cd}, \mathrm{Pb}, \mathrm{Zn}$ and $\mathrm{Ni}$ in particular are used extensively in these sectors and cause significant problems in water and other receiving environments. The most harmful, toxic and carcinogenic heavy metals known are $\mathrm{Pb}, \mathrm{Cd}, \mathrm{Zn}$ and Ni. Table 1 shows the properties, lethal doses $\left(\mathrm{LD}_{50}\right)$ and concentration values of common heavy metals identified ${ }^{7-9}$. Among the heavy metals polluting water environments the presence of hazardous heavy metals that are blacklisted by all countries of the world such as $\mathrm{Pb}, \mathrm{Cd}, \mathrm{Zn}$ and $\mathrm{Ni}$ are often detected ${ }^{10}$. These contaminants are generated frequently, thus, they accumulate in living organisms within the food chain and are liable for major health issues in both humans and animals ${ }^{11}$. It is paramount to check for heavy metals, which constitute one of the most hazardous and toxicant ingredients in wastewater ${ }^{12-14}$. Heavy metals are classed as metals and metalloids the atomic density of which exceed $4 \pm 1 \mathrm{~g} / \mathrm{cm}^{3}$. Up until now, many scientists have proposed a variety of potential physical and chemical processes for the removal of heavy metals from wastewaters, including ion exchange, chemical precipitation, electrochemical separation and reverse osmosis. The process of adsorption has often been preferred over other processes due to its low start-up costs, convenience, elasticity, 


\begin{tabular}{|l|l|l|l|l|l|l|l|l|l|l|}
\hline \multirow{2}{*}{ Heavy metals } & \multicolumn{9}{|l|}{ Permissible limits (mg/L) } & \multicolumn{4}{l|}{ Chemical properties } & \multicolumn{2}{l|}{ Toxicity mg/kg bw } \\
\cline { 2 - 11 } & WHO & USEPA & EU & VWR & PC & LogK & OW & $\mathbf{K}_{\text {OC }}$ & TWI & $\mathbf{L D}_{\text {50 }}$ \\
\hline $\mathrm{Ni}^{2+}$ & 0.07 & - & 0.02 & 163 & 1.91 & -0.571 & 1.20 & - & - \\
\hline $\mathrm{Zn}^{2+}$ & 0.005 & 0.005 & - & 139 & 1.65 & -0.471 & 1.20 & 1.0 daily & 20.2 \\
\hline $\mathrm{Pb}^{2+}$ & 0.001 & 0.0015 & 0.001 & 202 & 2.33 & 0.729 & 1.00 & 0.025 & - \\
\hline $\mathrm{Cd}^{2+}$ & 0.003 & 0.005 & 0.005 & 158 & 1.69 & -0.071 & 1.18 & 0.025 monthly & 5.2 \\
\hline
\end{tabular}

Table 1. Concentration and specific properties of some heavy metals in waters. VWR Van der Walls Radius $\left(10^{-12} \mathrm{~m}\right) ;$ PC Pauling Scale; $K_{O C}$ Sorption coefficient; $\log _{K O W}$ Octanol-water coefficient; bw: Bodyweight; TWI tolerable weekly intake for humans. $L D_{50}$ Median lethal dose values obtained in mice or rats.

high selectivity, ease of operation, environmental compatibility, insensibility to venomous components, and its major potential for the removal of hazardous contaminants. Many researchers have used natural materials such as carbon $^{15}$, silica ${ }^{16}$, activated carbon, zeolite ${ }^{17,18}$ in the adsorption process. In some studies, eggshells ${ }^{19}$, olive mill waste $^{20}$, peanuts, pistachio shells $\mathrm{s}^{21}$, sugar beet bagasse $\mathrm{e}^{22}$ and sunflowers ${ }^{23}$ have been used as the waste to remove heavy metals from wastewaters. The removal of heavy metal ions from waters using tea waste is essentially a threestep process: (i) adsorption, (ii) surface precipitation, and (iii) fixation ${ }^{24}$. Specific adsorption entails the surface complexation among functional groups and heavy metal ions in wastewater, and thus robust and permanent compounds are formed. $\mathrm{C}, \mathrm{H}, \mathrm{N}, \mathrm{O}$ and $\mathrm{S}$ are the main elements of tea waste. This is why the functional groups on the tea waste surface area are predominantly made of surface hydroxyl groups, which bring surrounding ions together and supply protons to the liquid medium. When electron-pair acceptor metal ions are in question, surface complexes are formed between metal ions and hydroxyl groups ${ }^{25}$. Pourbaix diagrams were used to properly evaluate the metal diversity of $\mathrm{Pb}, \mathrm{Ni}, \mathrm{Cd}, \mathrm{Zn}$ in the water samples subjected to chemical analysis. It was observed that for each metal analyzed, there was a large overlap between the chemical species predicted by the Pourbaix diagrams. The predominant species $\mathrm{Pb}, \mathrm{Ni}, \mathrm{Zn}, \mathrm{Cd}$ in the aqueous phase depends on the $\mathrm{pH}$ and Pourbaix diagram. The main species present at $\mathrm{pH} \leq 6$ are $\mathrm{Pb}^{2+}, \mathrm{Ni}^{2+}-\mathrm{Ni}_{2} \mathrm{H}, \mathrm{Zn}^{2+}, \mathrm{Cd}^{2+}-\mathrm{CdOH}^{+}$, while at $\mathrm{pH} \geq 7$ they are $\mathrm{Pb}(\mathrm{OH})_{2}-\mathrm{PbO}_{2}, \mathrm{NiOH}^{+}, \mathrm{Zn}(\mathrm{OH})_{2}-\mathrm{ZnO}_{2}{ }^{2-}$, and $\mathrm{Cd}(\mathrm{OH})_{2}-\mathrm{CdO}_{2}{ }^{2-18,21-26}$. The occurrence of these surface complexes, creating a three-dimensional phase during the removal of heavy metals from a medium by using tea wastes, can be described as surface precipitation. The diffusion of heavy metals into the tea waste is realized with the fixation mechanism, as the tea waste serves as an amorphous structure to which the method can be applied. The sorption kinetics are biphasic, with the first phase being the fast phase that is related with the larger area of available surfaces at the initiation of the process and the second phase being the slow stage phase which covered the diffusion in the micropores of the tea waste ${ }^{24}$.

The adsorbent is a crucial parameter in the adsorption system. There are many parameters including $\mathrm{pH}$ and temperature of the medium, dose of the used adsorbent, and the allowed contact time that affect the yield of the adsorbents when removing various pollutants from wastewater. The diversity of low-cost adsorbents, such as industrial by-products, agricultural waste, food waste, types of activated carbons, clay minerals, biomass and polymeric materials, and zeolites, has been extensively investigated to be used for water and wastewater ${ }^{20,27}$. It is common for agricultural wastes to be used in batch adsorption experiments ${ }^{28}$. Brewed tea waste (BTW), which is a kind of agricultural waste, emerges in large quantities every year around the world. Interestingly, tea waste contains an insoluble cell wall consisting of cellulose, lignin, tannin and structural proteins with specific functional groups that are effective in forming physicochemical reactions with heavy metals and other contaminants and, thus, can be used to remove harmful substances from solutions and wastewaters ${ }^{29}$. In recent years, heavy metal and paint removal has been achieved with modifications of natural materials. As a result, the cost must be considered despite the high removal efficiency. Both waste control and the evaluation of wastes defined as waste in terms of treatment are of great importance in adsorption. Many studies have examined the adsorbent properties of waste tea leaves or tea factory wastes for the removal of hazardous substances from wastewaters ${ }^{30}$. However, there are limited studies that have been conducted on BTW. The present study focused on used tea residues that had not received any treatment in terms of activation, coating or modification. Furthermore, tea waste was selected as an adsorbent for heavy metal elimination and the possibility of using BTW in the elimination of $\mathrm{Pb}, \mathrm{Cd}, \mathrm{Zn}, \mathrm{Ni}$ from watery environments was investigated. The adsorption behaviours of these metal ions in the tea waste were determined by observing the impacts of solution $\mathrm{pH}, \mathrm{BTW}$ concentrations and contact time. Various other significant adsorption properties were also investigated. In addition, the main purpose of this study was to help scientists select suitable adsorbents for the removal of target heavy metals and facilitate the development of new adsorbents.

\section{Results}

BTW characterization. The composition of BTW was determined and the results are given in Table $2^{31}$. The surface structure of the BTW was not sufficiently developed. Therefore, as the BTW was used as an adsorbent, its adsorption capacity was negatively affected by the structure of its surface in addition to other mechanisms that played important roles in the rate of adsorption. In aqueous mediums, sample $\mathrm{pH}$ is one of the most important factors affecting zeta potential. Zeta potential readings taken at different $\mathrm{pH}$ values provide vital data about the sample's surface and composition, such as the presence of functional groups. The zeta potential and the $\mathrm{pH}_{\mathrm{ZPC}}(\mathrm{pH}$ at point of zero charge) of the tea waste was $-20.58 \mathrm{mV}$ and $\mathrm{pH} 2.45$, respectively. The zeta 


\begin{tabular}{|l|l|l|c|}
\hline \multicolumn{2}{|l|}{$\begin{array}{l}\text { Proximate analysis (wt\%, as } \\
\text { received) }\end{array}$} & \multicolumn{2}{l|}{$\begin{array}{l}\text { Ultimate analysis } \\
\text { (wt\%, dry basis) }\end{array}$} \\
\hline Moisture & 7.20 & Carbon & 45.4 \\
\hline Volatile matter & 70.29 & Hydrogen & 5.7 \\
\hline Ash & 3.74 & Nitrogen & 2.9 \\
\hline Surface area & $0.913 \mathrm{~m}^{2} / \mathrm{g}$ & Oxygen & 46.0 \\
\hline Particle size & $3.35-5.00 \mathrm{~mm}$ & $\mathrm{~K}_{2} \mathrm{O}$ & 8.23 \\
\hline Pore capacity & $0.007 \mathrm{~cm}^{3} / \mathrm{g}$ & $\mathrm{CaO}$ & 3.23 \\
\hline
\end{tabular}

Table 2. Ultimate and proximate properties of BTW.

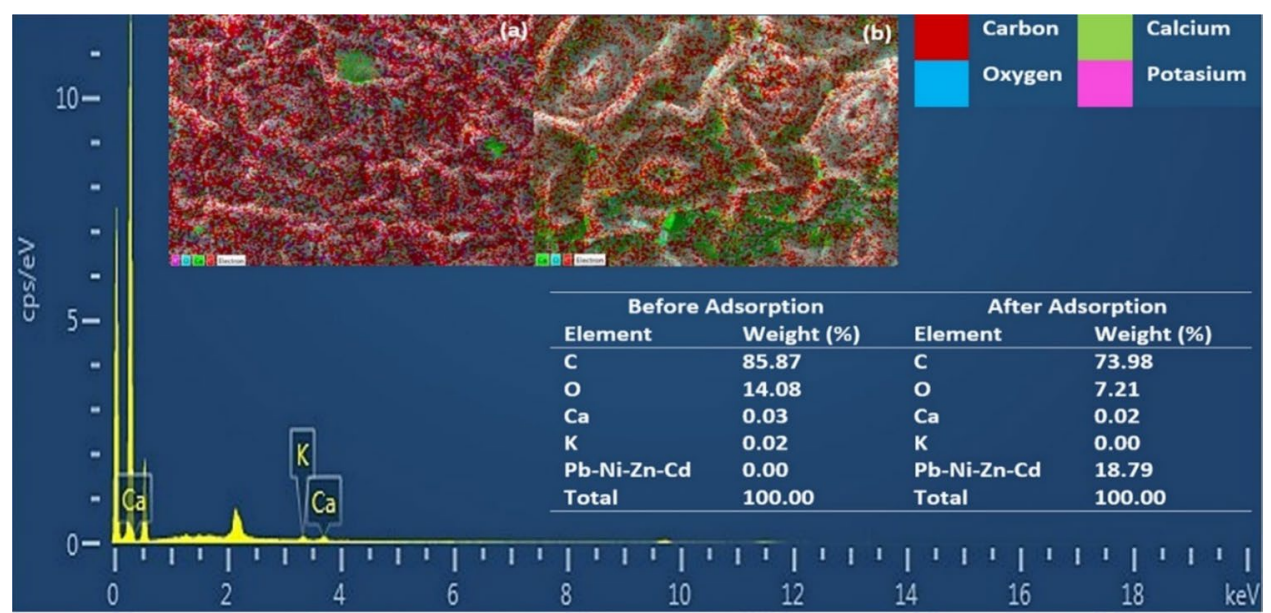

Figure 1. SEM and EDX (a) before and (b) after adsorption heavy metals by BTW.

\begin{tabular}{|l|l|l|l|}
\hline Before adsorption & After adsorption & Difference & Assignment \\
\hline 2916.62 & 2916.42 & +20 & Aliphatic C-H group \\
\hline 2849.35 & 2849.23 & +12 & Aliphatic C-H group \\
\hline 2160.69 & 2161.07 & 0 & $\mathrm{C}=\mathrm{O}$ stretching, $\mathrm{C}=\mathrm{O} / \mathrm{C}=\mathrm{C}$ stretching \\
\hline 1615.38 & 1614.97 & 0 & $\mathrm{C}-\mathrm{H}$ alkanes in aromatic rings \\
\hline 1516.44 & 1471.66 & +44 & $-\mathrm{CH}_{3}$ symmetric bending of $\mathrm{CH}_{3}$ \\
\hline 1165.56 & 1167.43 & -2 & $\mathrm{C}-\mathrm{O}$ stretching \\
\hline 718.33 & 718.31 & +2 & $\mathrm{C}-\mathrm{O}-\mathrm{H}$ stretching \\
\hline
\end{tabular}

Table 3. Main functional groups of BTW and heavy metals loaded on BTW.

potential of the BTW was always negative in the tested $\mathrm{pH}$ range of 2-10, indicating that the BTW was effective in attracting cations. These zeta potential values matched the data presented by Wan et al. ${ }^{32}$, who reported on the zeta potential of tea waste.

A SEM micrograph of the BTW is shown in Fig. 1. As its main components are cellulose and hemicellulose, the BTW presented a stem structure. In addition, it showed a structure of heterogeneous and wide porous surface, which are favorable properties when using the substance in the adsorption of heavy metals. Generally, rougher surface area and broadly distributed pores can offer an effective surface area and more opportunities for the binding of heavy metal particles. Particle size determines the surface area of an adsorbent. Small particle size adsorbents create a larger surface area available for adsorption. According to the results, it can be attributed to both functional groups and particle size that adsorption may be limited to the outer surface. The main functional groups of the BTW are summarized in Table 3. The FTIR of the BTW and heavy metal clinging to the BTW are presented in Fig. 2. As a result of the FTIR analysis, it can be said that aliphatic $\mathrm{C}-\mathrm{H}, \mathrm{C}-\mathrm{O}-\mathrm{H}$ and $\mathrm{C}-\mathrm{O}$ stretching functional groups in particular were involved in adsorption.

Effect of $\mathrm{pH}$. In this study, the $\mathrm{pH}$ values were adjusted to be in the range of 2.0-6.0. As heavy metals cannot dissolve at neutral or basic $\mathrm{pH}$ values, determining the degree of metal contamination in water at $\mathrm{pH} \geq 7 \mathrm{can}$ 


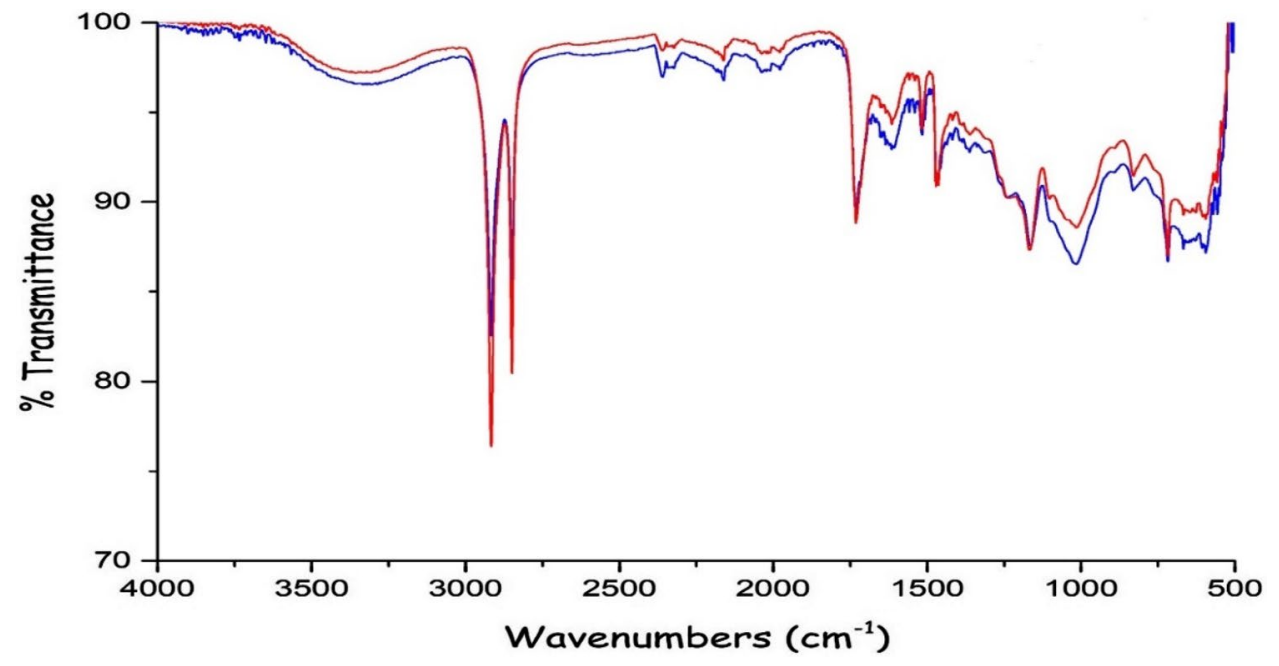

Figure 2. FTIR spectra before (red line), after (blue line) adsorption heavy metals by BTW.

be misleading. After $\mathrm{pH}$ 6, the formation precipitation of heavy metal ions as their own hydroxides may affect the adsorption results, therefore adsorption experiments were conducted in the $\mathrm{pH}$ range of 2-6. According to the Pourbaix diagram of $\mathrm{Pb}$ and $\mathrm{Zn}$, the $\mathrm{Pb}^{2+}$ and $\mathrm{Zn}^{2+}$ ions precipitated as $\mathrm{Pb}(\mathrm{OH})_{2}$ and $\mathrm{Zn}(\mathrm{OH})_{2}$ at $\mathrm{pH}$ values greater than 6 . However, at $\mathrm{pH}$ values lower than 6 , the removal of the $\mathrm{Pb}^{2+}$ and $\mathrm{Zn}^{2+}$ ions by adsorption onto BTW was possible. The values $\mathrm{pH}>6$ are close to the values at which $\mathrm{Cd}(\mathrm{OH})_{2}$ precipitates. They also match the $\mathrm{pH}$ value for the $\mathrm{Cd}(\mathrm{OH})_{2}$ precipitation in a cadmium-water environment, as explained in the Pourbaix diagram. According to the Pourbaix diagram, $\mathrm{Ni}^{2+}$ was mainly present as uncharged $\mathrm{Ni}_{2} \mathrm{H}$ when the $\mathrm{pH}$ was lower than 6 and as $\mathrm{NiOH}^{+}$and $\mathrm{HNiO}_{2}^{-}$when the $\mathrm{pH}(9-13)$ was higher ${ }^{33,34}$. As can be seen from Fig. 3a the removal percentage of the $\mathrm{Pb}$ and $\mathrm{Cd}$ ions was low when the $\mathrm{pH}$ was 2 or 3 as acidic conditions favour undissociated forms of functional groups. It was noted that when $\mathrm{pH}$ was 4 , the removal percentage of the $\mathrm{Pb}$ and Cd ions increased significantly from 74.09 to $91.06 \%$ for $\mathrm{Pb}, 54.73 \%$ to $79.71 \%$ for $\mathrm{Zn}$ and $74 \%$ to $82 \%$ for $\mathrm{Cd}$, respectively. The one-way ANOVA test showed that there was a significant relationship $(\mathrm{p}<0.01)$ between $\mathrm{Pb}^{2+}$ removal percentages with $\mathrm{pH}$ changes. When the effects of $\mathrm{pH}$ value on the removal percentage of the metals were examined, it was found that the highest removal percentage for $\mathrm{Ni}$ and $\mathrm{Zn}$ was achieved at $\mathrm{pH}$, and for $\mathrm{Cd}$ at $\mathrm{pH} 3(\mathrm{p}<0.01)$. Changing the $\mathrm{pH}$ of the solution from 5 to 6 made no difference to the results. Wasewar et al. ${ }^{35}$ investigated a wide range of $\mathrm{pH}$ values from 2 to 12 and reported that the maximum $\mathrm{Zn}$ removal of $92 \%$ was obtained at $\mathrm{pH}$ 4.2. At lower $\mathrm{pH}$ values the $\mathrm{H}+$ ions compete with metal cations for the electrostatic surface charges in the system decreasing the percentage of sorption. These outcomes regarding the $\mathrm{pH}$ amount are also parallel to various studies that used acidic $\mathrm{pH}^{14}$. Basu et al. ${ }^{1}$ investigated the adsorption potential of sugar beet bagasse to remove $\mathrm{Cr}(\mathrm{VI})$ from aqueous solutions under optimum conditions including a $\mathrm{pH}$ of 5 . They determined that removal efficiency was obtained to be $78.03 \%$. Baby et al. ${ }^{36}$ observed that the adsorption of $\mathrm{Pb}, \mathrm{Zn}, \mathrm{Cd}$ on palm kernel shell is best at $\mathrm{pH} 2-6$. The experimental results showed that the maximum removal percentages of $\mathrm{Pb}, \mathrm{Zn}$, Cd were $99.01 \%, 83.45 \%$, and $84.23 \%$ respectively. The effect of $\mathrm{pH}$ on $\mathrm{Ni}$ adsorption was investigated at a $\mathrm{pH}$ between 2 and 6 , a temperature of $20^{\circ} \mathrm{C}$ and an initial $\mathrm{Ni}$ ion concentration of $104.3 \mathrm{mg} / \mathrm{L}$. The level of metal adsorption was found to increase with the increase in $\mathrm{pH}$ from 2 to 6 . The Ni ion showed maximum adsorption capacity at a $\mathrm{pH}$ of 5 . At $\mathrm{pH}<6$ the predominant metal species were $\mathrm{Ni}^{2+}$ and $\mathrm{Ni}(\mathrm{OH})^{+}$. At values above $\mathrm{pH} 6$, metal hydroxide $\mathrm{Ni}(\mathrm{OH})_{2}$ is likely to precipitate. At low $\mathrm{pH}$, there were large amounts of $\mathrm{H}^{+}$ions that effectively competed with the $\mathrm{Ni}$ ions for the adsorption sites and reduced the metal uptake capacity. Heavy metals are often present in their cationic state and are often more solvable and active in water mediums at neutral to low $\mathrm{pH}$ values. The $\mathrm{pH}$ of the medium can be a deciding factor on the adsorbent's surface charge ${ }^{12}$.

Effect of BTW amount on the adsorption efficiency. As can be seen from Fig. 3b the increase in the BTW dose from 0.1 to $5 \mathrm{~g}$ in $100 \mathrm{~mL}$, increased the removal efficiency of $\mathrm{Pb}, \mathrm{Ni}, \mathrm{Zn}$ and Cd by the BTW from $49.71 \%(1.488 \mathrm{mg} / \mathrm{g})$ to $98.03 \%$ (1.197 $\mathrm{mg} / \mathrm{g})$, from $36 \%$ (1.652 $\mathrm{mg} / \mathrm{g})$ to $76 \%(1.457 \mathrm{mg} / \mathrm{g})$, from $46.61 \%$ $(2.532 \mathrm{mg} / \mathrm{g})$ to $85.03 \%(2.468 \mathrm{mg} / \mathrm{g})$ and from $41 \%(1.373 \mathrm{mg} / \mathrm{g})$ to $94 \%(1.163 \mathrm{mg} / \mathrm{g})$, respectively. These results were obtained at the optimal $\mathrm{pH}$ levels of $4(\mathrm{~Pb}$ and $\mathrm{Cd})$ and $5(\mathrm{Ni}$ and $\mathrm{Zn})$ and the optimum contact times $(\mathrm{Pb}=2 \mathrm{~min}, \mathrm{Ni}=30 \mathrm{~min}, \mathrm{Zn}=10 \mathrm{~min}$ and $\mathrm{Cd}=5 \mathrm{~min})$. This increase in yield was a result of the retention capacity of the active surface of the existing adsorbent for the $\mathrm{Pb}, \mathrm{Ni}, \mathrm{Zn}$ and $\mathrm{Cd}$ ions. In addition, the BTW amount can be decreased in accordance with the saturation of various regions on the BTW surface. From the results obtained, it can be observed that the significant level of less than 0.05 was obtained for BTW. Therefore, it can be concluded that the BTW was very effective in the removal of the $\mathrm{Pb}, \mathrm{Ni}, \mathrm{Zn}$ and $\mathrm{Cd}$ ions from aqueous solutions. The one-way ANOVA test showed a significant relationship $(\mathrm{p}<0.01)$ between different BTW concentrations and removal percentages of the heavy metal ions. In addition, there was no statistically significant difference between the results obtained with $1.5 \mathrm{~g}$ and $2 \mathrm{~g}$ BTW doses in the percentage removal of the $\mathrm{Pb}$ ions $(\mathrm{p}>0.01)$. Similar results were reported by Agarwal et al. ${ }^{37}$ for the adsorption of heavy metals using modified agricultural 

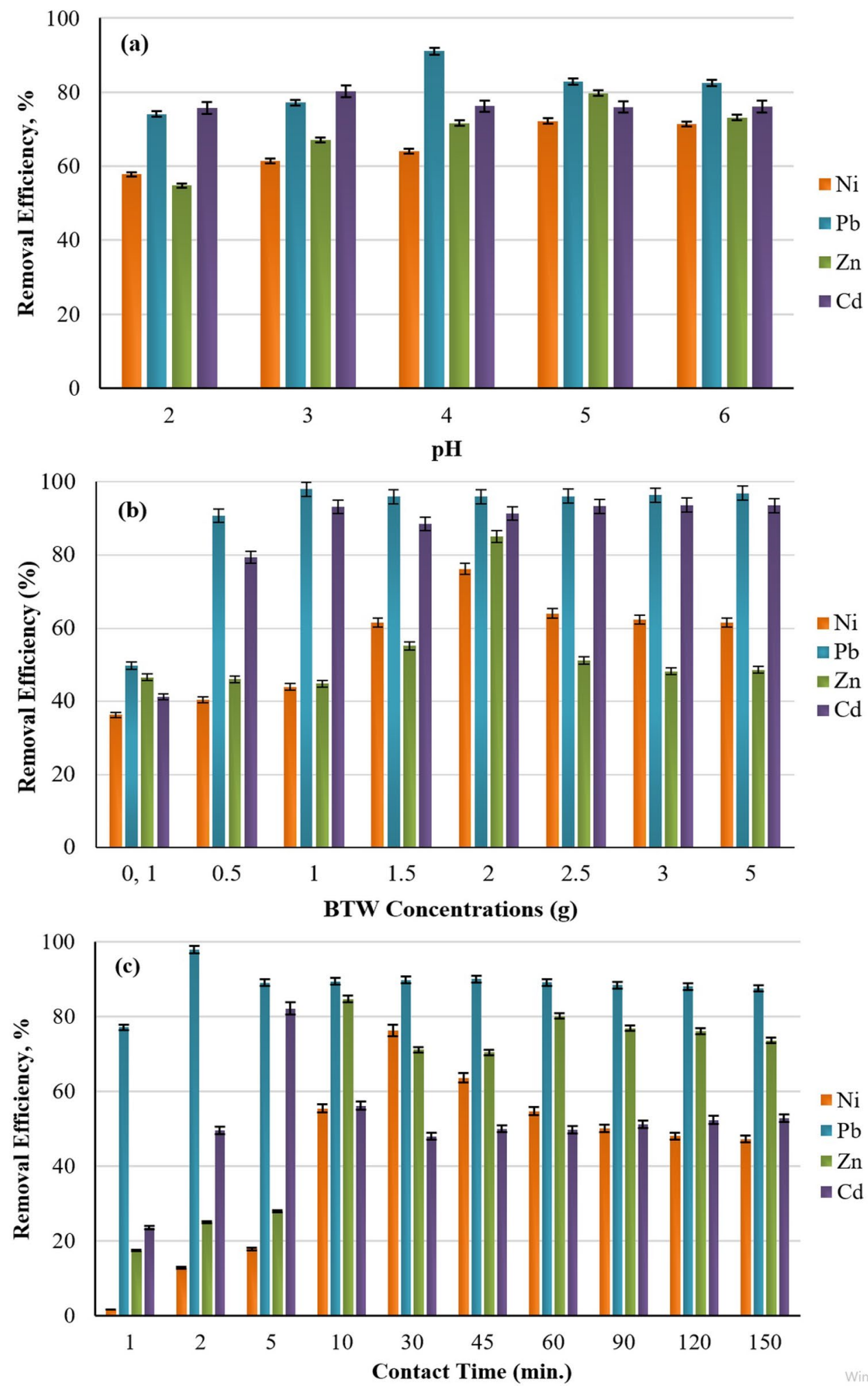

Figure 3. Impact of $\mathrm{pH}(\mathbf{a}), \mathrm{BTW}$ concentration (b), contact time (c) on the elimination of $\mathrm{Pb}, \mathrm{Cd}, \mathrm{Ni}, \mathrm{Zn}$ ions.

adsorbents. Thakur et al. ${ }^{38}$ investigated the elimination of $\mathrm{Cu}(\mathrm{II}), \mathrm{Pb}(\mathrm{II}), \mathrm{Cd}(\mathrm{II})$ and $\mathrm{Zn}(\mathrm{II})$ from wastewater by using activated rice husk with the batch adsorption process. In another study, walnut shells and the agricultural wastes of sunflowers, potatoes and canola have been used as biosorbents for the removal of heavy metals from aqueous solutions using batch experiments and the maximum adsorption capacity of the walnut shells was as 


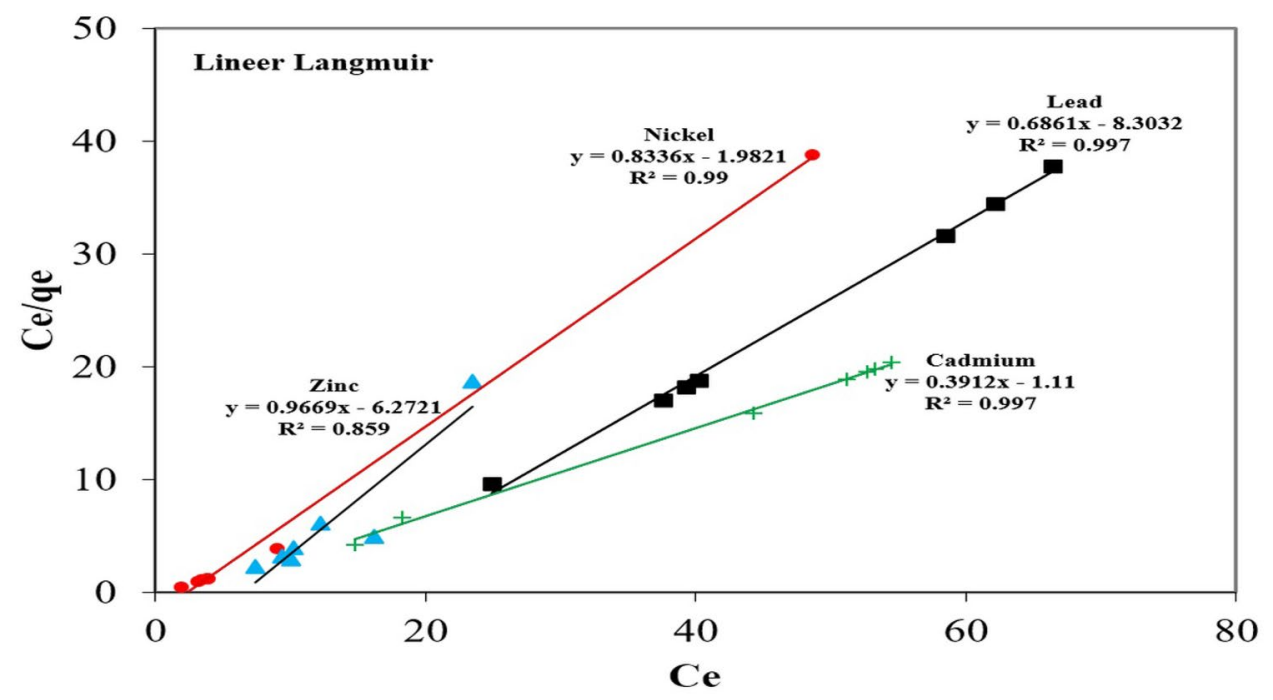

Figure 4. Langmuir isotherm curves of $\mathrm{Pb}, \mathrm{Cd}, \mathrm{Ni}$ and $\mathrm{Zn}$ adsorption by $\mathrm{BTW}$.

follows: Cd $(76.9 \mathrm{mg} / \mathrm{g})>\mathrm{Zn}(33.3 \mathrm{mg} / \mathrm{g})>\mathrm{Ni}(29.4 \mathrm{mg} / \mathrm{g})^{23}$. Previous studies have concluded that $\mathrm{Zn}$ can be removed at an $80 \%$ removal efficiency by using black tea waste $(20 \mathrm{~g})^{39}$. The experimental studies conducted within the scope of the present study were in line with the results of relevant studies in the literature ${ }^{40,41}$.

Effect of contact time and temperature. The adsorption of the $\mathrm{Pb}, \mathrm{Ni}, \mathrm{Zn}, \mathrm{Cd}$ ions was gauged at certain contact times for the initial $\mathrm{Pb}, \mathrm{Ni}, \mathrm{Zn}, \mathrm{Cd}$ concentrations of $96.71,104.30,98.70$ and $108 \mathrm{mg} / \mathrm{L}$, respectively. The removal efficiencies of the $\mathrm{Pb}, \mathrm{Ni}, \mathrm{Zn}$, Cd ions increased up to $60 \mathrm{~min}$ and then remained almost constant (Fig. 3c). As can be seen from Fig. $3 c$ the percentage of metal removal was initially higher $(2 \mathrm{~min}-97.97 \%$, $5 \mathrm{~min}-82 \%, 30 \mathrm{~min}-76 \%, 10 \mathrm{~min}-84.74 \%$ ). This may be due to the structure of the initially present BTW for the adsorption of the $\mathrm{Pb}, \mathrm{Ni}, \mathrm{Zn}, \mathrm{Cd}$ ions and a larger surface area. According to Fig. 3c, the metal uptake was fairly rapid for all concentrations examined and removal efficiency reached an equilibrium capacity of 50-97\% of adsorption in $60 \mathrm{~min}$. The one-way ANOVA indicated that there was a significant relationship $(\mathrm{p}<0.01)$ between the removal percentages of the $\mathrm{Pb}, \mathrm{Ni}, \mathrm{Zn}, \mathrm{Cd}$ ions and the increase in contact time. However, it was determined that similar percentage removal results were achieved for the $\mathrm{Pb}$ and $\mathrm{Cd}$ ions at certain contact times and that there was no statistical difference between the results $(\mathrm{p}>0.01)$. Similar findings have been reported in the removal of heavy metal ions by tea wastes ${ }^{42}$. In addition, some studies in the literature have reported similar results for heavy metals using different agricultural wastes ${ }^{43,44}$. Yang et al. ${ }^{29}$ conducted Ni(II) removal experiments using modified green tea waste and determined the maximum removal efficiency of $\mathrm{Ni}(\mathrm{II})$ as approximately $75 \%$ in $10 \mathrm{~min}$. Ghasemi et al. ${ }^{45}$ applied the adsorption method with tea waste for the removal of Cd from aqueous solutions. Their experimental results showed that the maximum removal of Cd with tea waste was $99.5 \%$ at $90 \mathrm{~min}$. Temperature is also an important factor when assessing the behaviour of heavy metals and their eventual removal from solutions ${ }^{46}$. When evaluating the effect of temperature on the process of the removal of heavy metals, each adsorbent and metal ion must be tested specifically to define the effect of temperature changes on the overall adsorption. In the present study, the adsorption efficiency was investigated by increasing the temperature from 20 to $40^{\circ} \mathrm{C}$ for $100 \mathrm{mg} / \mathrm{L}$ concentrations of $\mathrm{Pb}, \mathrm{Ni}, \mathrm{Zn}$ and $\mathrm{Cd}$. Accordingly, as tea wastes exposed to high temperatures were used, there was no change in the heavy metal removal efficiencies in accordance with temperature changes (data not shown).

Adsorption isotherm and kinetic models. In this study, the Langmuir, Freundlich, Temkin and Dubinin-Radukevich isotherms were employed to define the relationship between the adsorbate in the liquid phase and the adsorbate on the surface of the adsorbent. The regression correlation coefficient $\left(\mathrm{R}^{2}\right)$ for the Temkin, Freundlich, Dubinin-Radukevich isotherms were relatively small in relation to that of the Langmuir isotherm. As can be observed from Table 3, the equilibrium adsorption data were better defined when the Langmuir isotherm model was used. The order of appropriateness of the isotherm models was as follows: Langmuir $>$ Temkin $>$ Freundlich $>$ Dubinin-Radukevich (Fig. 4). As a result of adsorption studies, the Langmuir isotherm was found to be the most suitable for the heavy metals according to the $\mathrm{R}^{2}$ value. Therefore, only this isotherm model was used for the calculation of error functions $(\mathrm{ErF})^{47,48}$. The results of the error functions are presented in Table 3. If the results from an isotherm are similar or close to four different function data, the error value should be small. As a result of the calculations, it was determined that the HYBRID error function gave the best result. The values of the Langmuir isotherm in this study indicated a positive interaction between the adsorbate and the BTW, which is valid proof of an ion-exchange mechanism taking place throughout the adsorption process (Table 4). Studies in the literature conducted on the adsorption of different heavy metals with various agricultural waste adsorbents have indicated that the removal of the heavy metal ions was fitted to the Langmuir isotherm ${ }^{49,50} .1 / \mathrm{n}$ in the Freundlich equation can be seen as a reflection of the difficulty of the 


\begin{tabular}{|c|c|c|c|c|c|}
\hline Models & Parameters & $\mathrm{Ni}$ & $\mathbf{P b}$ & Zn & Cd \\
\hline \multirow{4}{*}{ Langm } & $\mathrm{q}_{\mathrm{m}}(\mathrm{mg} / \mathrm{g})$ & 1.457 & 1.197 & 2.468 & 1.163 \\
\hline & $\mathrm{K}_{\mathrm{L}}(\mathrm{L} / \mathrm{mg})$ & 0.083 & 0.405 & 0.218 & 0.173 \\
\hline & $\mathrm{R}^{2}$ & 0.997 & 0.997 & 0.997 & 0.859 \\
\hline & $\mathrm{R}_{\mathrm{L}}$ & 0.13 & 0.03 & 0.05 & 0.06 \\
\hline \multirow{4}{*}{$\mathrm{ErF}$} & MPSD & 16.827 & 20.951 & 12.696 & 14.498 \\
\hline & \begin{tabular}{|l|} 
HYBRID \\
\end{tabular} & 1.846 & 1.858 & 1.893 & 1.764 \\
\hline & NSD & 15.192 & 15.214 & 12.928 & 10.367 \\
\hline & ARE & 12.853 & 10.561 & 9.876 & 11.135 \\
\hline \multirow{3}{*}{ Frlich } & $\mathrm{K}_{\mathrm{F}}(\mathrm{mg} / \mathrm{g})$ & 2.538 & 5.189 & 6.175 & 4.981 \\
\hline & $\mathrm{n}$ & 15.128 & 2.734 & 4.782 & 5.442 \\
\hline & $\mathrm{R}^{2}$ & 0.312 & 0.961 & 0.577 & 0.528 \\
\hline \multirow{2}{*}{ Temkin } & $\mathrm{A}_{\mathrm{T}}$ & 0.825 & 0.545 & 0.647 & 0.964 \\
\hline & $\mathrm{R}^{2}$ & 0.956 & 0.963 & 0.571 & 0.454 \\
\hline \multirow{2}{*}{$\mathrm{D}-\mathrm{R}$} & $\varepsilon(\mathrm{kj} / \mathrm{mol})$ & 1.036 & 7.808 & 2.148 & 9.569 \\
\hline & $\mathrm{R}^{2}$ & 0.926 & 0.571 & 0.983 & 0.389 \\
\hline \multirow{2}{*}{$\mathrm{PFO}$} & $\mathrm{k}_{1}(1 / \mathrm{min})$ & 0.037 & 0.045 & 0.065 & 0.034 \\
\hline & $\mathrm{R}^{2}$ & 0.742 & 0.940 & 0.708 & 0.606 \\
\hline \multirow{2}{*}{ PSO } & $\mathrm{k}_{2}(\mathrm{mg} / \mathrm{g} / \mathrm{min})$ & 0.0006 & 0.032 & 0.026 & 0.017 \\
\hline & $\mathrm{R}^{2}$ & 0.921 & 0.983 & 0.967 & 0.933 \\
\hline \multirow{2}{*}{ ID } & $\mathrm{k}_{\mathrm{d}}\left(\mathrm{mg} / \mathrm{g} / \mathrm{min}^{1 / 2}\right)$ & 0.937 & 2.507 & 0.806 & 2.933 \\
\hline & $\mathrm{R}^{2}$ & 0.385 & 0.474 & 0.643 & 0.514 \\
\hline \multirow{3}{*}{ Elovich } & $\alpha(\mathrm{mg} / \mathrm{g} / \mathrm{min})$ & 8.967 & 1.122 & 7.578 & 2.796 \\
\hline & $\beta$ (g/mg) & 0.49 & 0.91 & 0.47 & 0.90 \\
\hline & $\mathrm{R}^{2}$ & 0.716 & 0.917 & 0.619 & 0.765 \\
\hline
\end{tabular}

Table 4. Kinetics, isotherms constants and error functions for $\mathrm{Pb}, \mathrm{Cd}, \mathrm{Ni}$ and $\mathrm{Zn}$.

adsorption behaviour. In general, when $1 / \mathrm{n}<0.5$ the experiment system is readily executed. The experiment system only becomes challenging when $1 / \mathrm{n}>0.5^{51}$. In this study, $1 / \mathrm{n}$ was less than 0.5 when the $\mathrm{Pb}, \mathrm{Cd}, \mathrm{Zn}$ and $\mathrm{Ni}$ ions were adsorbed onto BTW, suggesting that the adsorption of the $\mathrm{Pb}, \mathrm{Cd}, \mathrm{Ni}$ and $\mathrm{Zn}$ ions with BTW was easily conducted. The Langmuir isotherm model was applied with ease to the adsorption process and the average maximum adsorption capacities of the $\mathrm{Pb}, \mathrm{Ni}, \mathrm{Cd}$, and $\mathrm{Zn}$ ions were $1.197 \mathrm{mg} / \mathrm{g}, 1.457 \mathrm{mg} / \mathrm{g}, 1.163 \mathrm{mg} / \mathrm{g}$ and $2.468 \mathrm{mg} / \mathrm{g}$, respectively. The results obtained were in accordance with the Langmuir model. This shows that the adsorption experiments were homogeneous. The scatter plots between the experimentally observed qexperimental $\left(q_{e \text { exp }}\right)$ and model-calculated $\left(q_{e, \text { cal }}\right)$ values for the isotherms are presented in Fig. 5 . The potential of the $\mathrm{BTW}$ was assessed by comparing the adsorption capacity of the $\mathrm{Pb}, \mathrm{Cd}, \mathrm{Zn}$ and $\mathrm{Ni}$ ions with various agricultural wastes adsorbents as shown in Table 5. It is clear that from the collected data that the BTW is effective in the removal of the $\mathrm{Pb}, \mathrm{Cd}, \mathrm{Zn}$ and $\mathrm{Ni}$ ions.

The basic coefficients of the different kinetics are given in Table 4. Among the kinetic studies conducted, the Pseudo-second-order (PSO) $\left(\mathrm{R}^{2}=0.99\right)$ was able to express the adsorption in this study clearly. The PSO model consisted of the external liquid film diffusion, surface adsorption and intra-particle diffusion processes ${ }^{19,39,45,52}$. Therefore, the results of this model can be accepted as a clearer and more reliable description of the adsorption mechanism between the BTW and the $\mathrm{Pb}, \mathrm{Cd}, \mathrm{Zn}$ and Ni ions. The PSO model further suggested that the process was one of chemisorption, which is the rate-limiting step for the adsorption of the selected heavy metals onto the BTW (Fig. 6). It means that the adsorption mechanism was controlled by electrostatic interaction in the solid/liquid medium with the reduced effect of the chemical reaction between the $\mathrm{BTW}$ and $\mathrm{Pb}, \mathrm{Ni}, \mathrm{Cd}$, and $\mathrm{Zn}$ ions. The PSO model with higher $\mathrm{R}^{2}$ values better explains the fact that there may have been a speed limitation between the adsorption, the exchange of electrons or the BTW and the $\mathrm{Pb}, \mathrm{Ni}, \mathrm{Cd}$, and $\mathrm{Zn}$ ions. According to the $\mathrm{k}_{2}$ constant, the adsorption ratio of the polluting cations onto the BTW occurred in the following sequence: $\mathrm{Zn}>\mathrm{Cd}>\mathrm{Pb}>\mathrm{Ni}$. According to previous studies that focused on the adsorption of heavy metals using various methods, the removal of the $\mathrm{Pb}, \mathrm{Cd}, \mathrm{Zn}$ and $\mathrm{Ni}$ ions is suitable for PSO kinetic modelling ${ }^{19,39,45,52}$. The findings of the present study regarding the $\mathrm{Pb}, \mathrm{Cd}, \mathrm{Zn}$ and $\mathrm{Ni}$ ions showed distinct correlation with the results of previous studies conducted on the topic.

\section{Conclusion}

The BTW was determined as an efficient adsorbent in the removal of $\mathrm{Pb}, \mathrm{Ni}, \mathrm{Cd}$, and $\mathrm{Zn}$ from wastewaters. The adsorption rate was rapid during the initial time periods. Equilibrium times of 2, 10, 30 and 5 min were required for the adsorption of $\mathrm{Pb}, \mathrm{Zn}, \mathrm{Ni}, \mathrm{Cd}$ ions onto BTW, respectively. The adsorption process explained by the Langmuir isotherm had a monolayer adsorption capacity of $1.197 \mathrm{mg} / \mathrm{g}, 1.457 \mathrm{mg} / \mathrm{g}, 1.163 \mathrm{mg} / \mathrm{g}$ and $2.468 \mathrm{mg} / \mathrm{g}$, for the $\mathrm{Pb}, \mathrm{Ni}, \mathrm{Cd}$, and $\mathrm{Zn}$ ions, respectively. HYBRID was found to be suitable for Langmuir in the adsorption of 


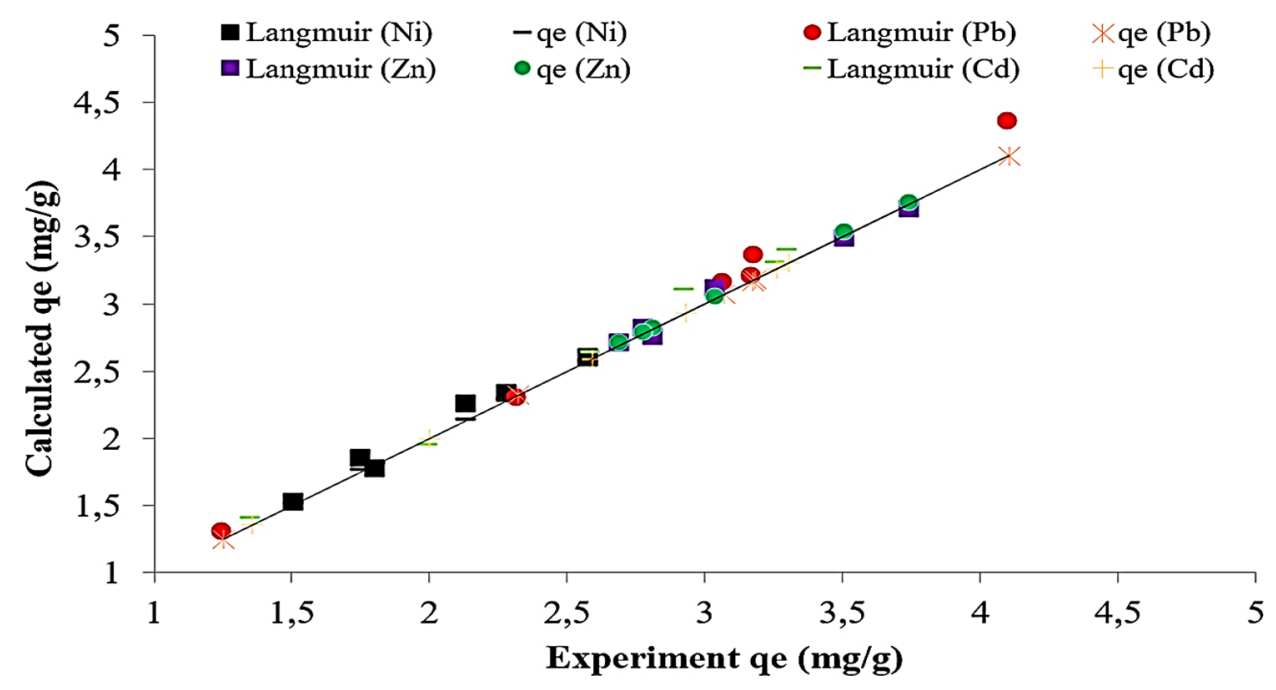

Figure 5. The plot between experimentally observed and calculated values of Langmuir.

\begin{tabular}{|c|c|c|c|c|c|c|c|c|c|c|}
\hline \multirow[b]{2}{*}{ Adsorbent } & \multirow[b]{2}{*}{ metal } & \multicolumn{5}{|c|}{ Optimum parameters } & \multirow[b]{2}{*}{$\%$ Yield } & \multirow[b]{2}{*}{ Models } & \multirow[b]{2}{*}{$q_{m}(m g / g)$} & \multirow[b]{2}{*}{ References } \\
\hline & & $\mathrm{m}(\mathrm{g})$ & pH & $\mathrm{C}_{0}(\mathrm{mg} / \mathrm{L})$ & $t(\min )$ & $\mathrm{T}\left({ }^{\circ} \mathrm{C}\right)$ & & & & \\
\hline MGTW & $\mathrm{Ni}^{+2}$ & 0.3 & 3.0 & 5 & 10 & 33 & 75 & Langm/PSO & 0.316 & 29 \\
\hline SCG & $\mathrm{Zn}^{+2}$ & 2.5 & 5.0 & 100 & 300 & 55 & 84.55 & Frlich/PSO & 5.25 & 52 \\
\hline WBT & $\mathrm{Zn}^{+2}$ & 20 & 5.0 & 100 & 250 & 25 & 80 & Langm// Frlich /PSO & 166.7 & 39 \\
\hline TW & $\mathrm{Cd}^{+2}$ & 10 & 5.0 & 5 & 90 & 20 & 99.5 & Langm// Frlich /PSO & 1.76 & 45 \\
\hline WS & $\mathrm{Pb}^{+2}$ & 1.0 & 4.0 & 100 & 2 & 20 & 90 & Langm//PSO & 9.912 & 19 \\
\hline TW & $\mathrm{Cd}^{+2}$ & 0.1 & 5.0 & 20 & 60 & 25 & 45 & Langm// Frlich /PSO & 16.87 & 32 \\
\hline TW & $\mathrm{Pb}^{+2}$ & 0.1 & 5.0 & 100 & 60 & 25 & 85 & Langm// Frlich /PSO & 33.49 & 32 \\
\hline \multirow{4}{*}{ BTW } & $\mathrm{Pb}^{+2}$ & 1.0 & 4.0 & 100 & 2 & 20 & 97.97 & Langm/PSO & 1.197 & \multirow{4}{*}{ In This Study } \\
\hline & $\mathrm{Cd}^{+2}$ & 1.0 & 4.0 & 100 & 5 & 20 & 84.74 & Langm/PSO & 1.163 & \\
\hline & $\mathrm{Ni}^{+2}$ & 2.0 & 5.0 & 100 & 30 & 20 & 82 & Langm/PSO & 1.457 & \\
\hline & $\mathrm{Zn}^{+2}$ & 2.0 & 5.0 & 100 & 10 & 20 & 76 & Langm/PSO & 2.468 & \\
\hline
\end{tabular}

Table 5. Adsorption capacities and yield of various tea waste based materials for the removal of $\mathrm{Pb}, \mathrm{Cd}, \mathrm{Ni}$ and $\mathrm{Zn}$ ions. MGTW modified green tea waste; $T W$ tea waste; $W B T$ waste black tea; SCG spent coffee grounds; $O P$ olive pomace; $W S$ walnut shell.

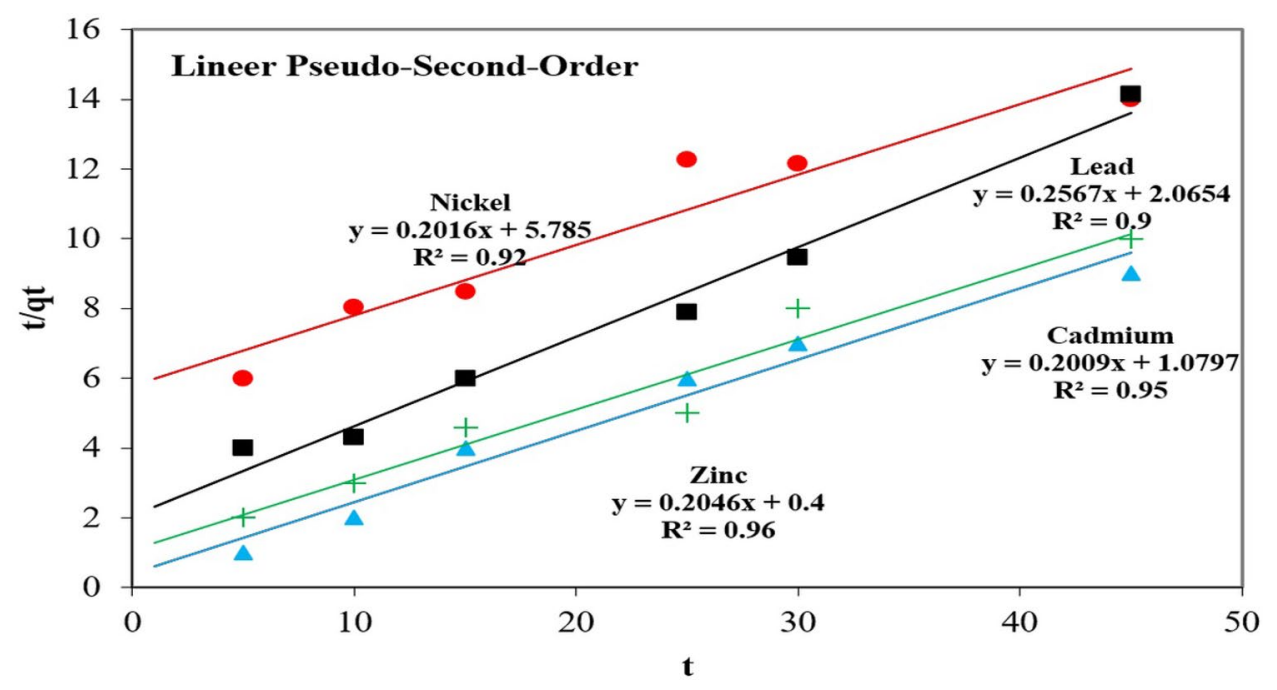

Figure 6. PSO kinetic curves of $\mathrm{Pb}, \mathrm{Cd}, \mathrm{Ni}$ and $\mathrm{Zn}$ adsorption by BTW. 
the heavy metals onto BTW. In addition, as a result of the kinetic studies it was determined that the PSO model was the most suitable kinetic model for the $\mathrm{Pb}, \mathrm{Ni}, \mathrm{Cd}$, and $\mathrm{Zn}$ ions. The maximum adsorption of $\mathrm{Pb}$ and $\mathrm{Cd}$ was achieved at $\mathrm{pH} 4$, while for $\mathrm{Ni}$ and $\mathrm{Zn}$ it was achieved at $\mathrm{pH}$ 5. The highest removal rates were in the order of $\mathrm{Pb}$ $(97.97 \%)>\mathrm{Ni}(82 \%)>\mathrm{Zn}(76 \%)>\mathrm{Cd}(84.74 \%)$. The adsorption rate and capacity were dependent on the BTW dose, solution concentration and particle size. The results of this study showed that BTW was a more efficient adsorbent compared to some of the treated biomass materials and that BTW could be suitably used as an alternative and effective adsorbent material for the removal of $\mathrm{Pb}, \mathrm{Ni}, \mathrm{Cd}$, and $\mathrm{Zn}$ ions from synthetic wastewaters.

\section{Methods}

Adsorbent preparation and characterization. Before being used as an adsorbent the BTW was required to go through several preliminary steps, such as grinding, sieving and washing. The BTW was obtained from food units on the campus of Aksaray University. The collected BTW were washed and then boiled at $100^{\circ} \mathrm{C}$ for colour removal. Then, they were then dried in sunlight for an average of two days. The naturally dried BTW were stored in a $60{ }^{\circ} \mathrm{C}$ incubator for $48 \mathrm{~h}$. Next, the BTW was pulverized by a mixer and sieved. Spectra in the range of $600-4000 \mathrm{~cm}^{-1}$ were determined by the Fourier transform infrared spectrometer (FTIR) (Thermo Scientific-Nicolet iS5) to identify the functional groups of the BTW samples. Scanning electron microscope (SEM) and energy-dispersive X-ray spectroscopy (EDS) analysis (Hitachi-SU 1510) were performed using a microscope equipped with an energy dispersive analytical system operating at an acceleration voltage of $5-15 \mathrm{kV}$ and an EDAX Apollo detector. The surface area measurement was performed using a Quantachrome-Quadrasorb Evo 4 brand device with the Brunauer, Emmett, and Teller (BET) method in a $77 \mathrm{~K}$ liquid nitrogen medium based on the $\mathrm{N}_{2}$ gas technique. The elemental composition for the adsorbent material was determined using an elemental analyzer (Perkin-Elmer 2400). Proximate (ash, moisture, etc.) experiments were performed according to the ASTM D 2866-94 $4^{53}$ and ASTM D $2867-95^{54}$ methods. A zeta meter was used to measure the zeta potential of the BTW (Pen Kern Laser Zee 3.0, USA). For this purpose, $0.05 \mathrm{~g}$ of the BTW was diluted in $500 \mathrm{~mL}$ of deionize water with $0.01 \mathrm{~mol} / \mathrm{L} \mathrm{NaNO}_{3}$ solution.

Batch adsorption experiments. In this study, the performance of the adsorption process using the BTW for the removal of heavy metals from aqueous solution was investigated on a laboratory scale with a batch test system. $100.0 \mathrm{mg}$ of the BTW was placed in $250 \mathrm{~mL}$ Erlenmeyer flasks that contained $100 \mathrm{~mL}$ solution with a concentration of the metals. All of the metal ions were studied individually. The initial $\mathrm{pH}$ value of the prepared synthetic wastewater was between 5.8 and 6.1. The $\mathrm{pH}$ value of the solution was changed using $1.0 \mathrm{M}$ HNO3 or $\mathrm{NaOH}$ solution as needed during the experiments. The $\mathrm{pH}$ values were adjusted to be in the range of 2.0-6.0. Subsequently, the flasks were shaken in a shaking incubator (Model G-25) with a thermostat at $150 \mathrm{rpm}$ for $24 \mathrm{~h}$ at $20^{\circ} \mathrm{C}$. Afterwards, the samples were filtered to extract the fine BTW particles and analyzed to detect the metal ions present in the fluids. The overall uptake of the studied metals was determined by measuring the metal mass in the fluid before and after the tests. Every batch was performed twice to increase the reliability of the data. The optimum $\mathrm{pH}$ and time was determined at the constant values of initial $\mathrm{Pb}, \mathrm{Ni}, \mathrm{Zn}$ and $\mathrm{Cd}$ concentrations and adsorbent dosages. Finally, the isotherms and kinetics of the adsorption of the heavy metals onto the BTW were determined separately. All of the chemicals used were purchased from Merck and Sigma. The contaminated solutions were prepared by dissolving the heavy metal salts in deionized water. The $\mathrm{Pb}, \mathrm{Cd}, \mathrm{Zn}$ and Ni ions were used as the model pollutants. Four different stock solutions were prepared for the selected heavy metals. Adsorption studies were performed separately for each ion. The $1000 \mathrm{mg} / \mathrm{L}$ stock solutions containing $\mathrm{Cd}, \mathrm{Pb}, \mathrm{Ni}$ and $\mathrm{Zn}$ were obtained from $3 \mathrm{CdSO}_{4} \cdot 8 \mathrm{H}_{2} \mathrm{O}, \mathrm{Pb}\left(\mathrm{NO}_{3}\right)_{2}, \mathrm{NiCl}_{2} \cdot 6 \mathrm{H}_{2} \mathrm{O}$ and $\mathrm{Zn}\left(\mathrm{NO}_{3}\right)_{2}$ (Sigma-Aldrich Chemie $\mathrm{GmbH}$, Germany), respectively. The working solutions of $100 \mathrm{mg} / \mathrm{L} \mathrm{Pb}, \mathrm{Ni}, \mathrm{Cd}$ and $\mathrm{Zn}$ were prepared from the stock solution by serial dilutions. Although the concentrations of heavy metals in natural waters are generally below $100 \mathrm{mg} / \mathrm{L}$, this study demonstrated that the existing adsorption process can also be used in industrial wastewater with high heavy metal concentrations such as the battery and metal coating industries. In addition, the $\mathrm{Pb}, \mathrm{Ni}$, $\mathrm{Cd}$ and $\mathrm{Zn}$ ion concentrations of the synthetically prepared wastewater were used at $100 \mathrm{mg} / \mathrm{L}$ concentration to represent real industrial wastewaters. The concentrations of the heavy metals in the studied samples were measured using a standard method with an inductively coupled plasma-optical emission spectrometer (ICP-OES) (Shimadzu-1700, Japan). All laboratory studies were repeated three times and the average numbers were used in the calculations. The removal and adsorption rates were calculated using the following equations:

$$
\begin{gathered}
\mathrm{q}_{\mathrm{e}}=\frac{\left(\mathrm{C}_{0}-\mathrm{C}_{\mathrm{e}}\right) \times \mathrm{V}}{1000 \mathrm{xm}} \\
\mathrm{Y}(\%)=\frac{\left(\mathrm{C}_{0}-\mathrm{C}_{\mathrm{e}}\right)}{\mathrm{C}_{0}} \times 100
\end{gathered}
$$

In these equations, $\mathrm{Y}$ is the rate of removal of $\mathrm{Pb}, \mathrm{Cd}, \mathrm{Ni}$ and $\mathrm{Zn}$ ions (\%). $\mathrm{C}_{0}$ and $\mathrm{C}_{\mathrm{e}}$ are respectively the initial and final concentrations of $\mathrm{Pb}, \mathrm{Cd}, \mathrm{Ni}$ and $\mathrm{Zn}(\mathrm{mg} / \mathrm{L})$. m represents the mass of BTW $(\mathrm{mg})$. The volume of the solution $(\mathrm{mL})$ is indicated with $\mathrm{V}$, where qe is the amount of adsorbed $\mathrm{Pb}, \mathrm{Cd}, \mathrm{Ni}$ and $\mathrm{Zn}$ ions by the BTW (mg/g).

Assessment of different models and error functions for selected heavy metals. The Freundlich, Langmuir, Dubinin-Radushkevich and Temkin isotherms were used extensively to define the relationship between the $\mathrm{Pb}, \mathrm{Cd}, \mathrm{Ni}$ and $\mathrm{Zn}$ ions in the synthetic water with BTW. The isotherm species of Freundlich (F) (3), Langmuir (L) (4), Dubinin-Radushkevich (D-R) (5), Temkin (T) (6), separation factor $\left(R_{L}\right)(7)$ were placed to the empirical results ${ }^{55-59}$. 


$$
\begin{gathered}
q_{e}=K_{F} \sqrt[n]{C_{e}} \\
q_{e}=\frac{q_{m} K_{L} C_{e}}{1+K_{L} C_{e}} \\
\text { In } q_{e}=\operatorname{In~} \mathrm{q}_{\mathrm{m}}-\beta \epsilon^{2} \\
q_{e}=\frac{R T}{b_{T}} \ln \left(\mathrm{A}_{\mathrm{T}} \mathrm{C}_{\mathrm{e}}\right) \\
\mathrm{R}_{\mathrm{L}}=\frac{1}{1+\mathrm{K}_{\mathrm{L}} \mathrm{C}_{0}} \\
q_{t}=\mathrm{q}_{e}\left(1-e^{-k_{1} t}\right) \\
q_{t}=\frac{K_{2} q_{e}^{2} t}{1+\mathrm{k}_{2} q_{e} t} \\
\mathrm{q}_{\mathrm{t}}=\frac{1}{\beta} \ln (\alpha \beta)+\frac{1}{\beta} \ln (\mathrm{t}) \\
\mathrm{q}_{\mathrm{t}}=\mathrm{K}_{\mathrm{d}} \mathrm{t}^{0.5}
\end{gathered}
$$

$\mathrm{C}_{\mathrm{e}}$ : balance amount of $\mathrm{Pb}, \mathrm{Cd}, \mathrm{Ni}$ and $\mathrm{Zn}$ ions $(\mathrm{mg} / \mathrm{L})$. $\mathrm{q}_{\mathrm{e}}$ : the number of heavy metals-BTW at balance (mg/g). $\mathrm{qm}$ : the maximum adsorption capacity $(\mathrm{mg} / \mathrm{g}), \mathrm{K}_{\mathrm{L}}$ : Langmuir constant $(\mathrm{L} / \mathrm{mg}) . \mathrm{K}_{\mathrm{F}}$ and $1 / \mathrm{n}$ : Freundlich constants. $\mathcal{E}$ and $\mathrm{R}(8.314 \mathrm{~J} / \mathrm{mol} \mathrm{K})$ specific constants and $\mathrm{T}$ is a temperature $(\mathrm{K})$. Temkin isotherm equilibrium binding constant is $\mathrm{A}_{\mathrm{T}}(\mathrm{L} / \mathrm{mg}), \mathrm{b}_{\mathrm{T}}(\mathrm{J} / \mathrm{mol})$ : Temkin isotherm constants. Adsorption kinetics are used to examine the changes in adsorption in a time period and can provide information about the experiment system. In our research, various non-linear kinetics suitable for the system were tested ${ }^{60}$. Pseudo-first order (PFO) (Eq. (8)), pseudo second-order (PSO) (Eq. (9)) Elovich model (Eq. (10)) and intraparticle diffusion (ID) (Eq. (11)): $\mathrm{q}_{\mathrm{e}}$, $\mathrm{q}_{\mathrm{t}}$ : the amounts of heavy metals adsorbed $(\mathrm{mg} / \mathrm{g})$ at balance. $\mathrm{k}_{1}(1 / \mathrm{min})$ : the PFO parameter. $\mathrm{k}_{2}, \mathrm{k}_{\mathrm{d}}$ : the PSO parameter. a $(\mathrm{mg} / \mathrm{g} / \mathrm{min})$ : The chief adsorption rate.

Statistical analysis. SPS 22.0.0 software (SPSS Inc., Chicago, USA) was used to gain insight into the effectiveness of the BTW in removing the heavy metal ions from the aqueous solutions. For this purpose, the one-way analysis of variance (ANOVA) test was applied at a 99\% confidence interval $(\mathrm{p}<0.01)$. Before the ANOVA test, all data passed the normality test. Then, the Duncan test was carried out to compare the means of each parameter. A minimum of three repeated measurements were performed to detect variability. The results obtained are presented in the bar charts as mean and standard deviation (Mean $\pm \mathrm{sd}$ ).

Received: 8 April 2020; Accepted: 5 October 2020

Published online: 16 October 2020

\section{References}

1. Basu, M., Guha, A. K. \& Ray, L. Adsorption of cadmium ions by cucumber peel in continuous mode. Int. J. Environ. Sci. Technol. 16, 237-248 (2019).

2. Yu, S. et al. Boron nitride-based materials for the removal of pollutants from aqueous solutions: a review. Chem. Eng. J. 333, 343-360 (2018).

3. Xie, X. et al. Preparation magnetic cassava residue microspheres and its application for $\mathrm{Cu}(\mathrm{II})$ adsorption. J. Environ. Chem. Eng. 5, 2800-2806 (2017).

4. Basu, M., Guha, A. K. \& Ray, L. Adsorption of lead on cucumber peel. J. Clean. Prod. 151, 603-615 (2017).

5. Zhou, M. et al. Total concentrations and sources of heavy metal pollution in global river and lake water bodies from 1972 to 2017. Glob. Ecol. Conserv. 22, e00925 (2020).

6. Kacmaz, H. Assessment of heavy metal contamination in natural waters of Dereli, Giresun: an area containing mineral deposits in northeastern Turkey. Environ. Monit. Assess. 192, 91 (2020).

7. USEPA. National Primary Drinking Water Regulations. United States Environmental Protection Agency, Washington, DC. https ://www.epa.gov/ground-water-and-drinking-water/national-primary-drinking-water-regulations. (2019).

8. WHO. Guidelines for Drinking-Water Quality, Brazil. https://apps.who.int/iris/bitstream/handle/10665/254637/9789241549950eng.pdf;jsessionid=347132493F49421E89E02B7B25E34359? sequence=1 (2017).

9. Vareda, J. P., Valente, A. J. M. \& Duraes, L. Assessment of heavy metal pollution from anthropogenic activities and remediation strategies: a review. J. Environ. Manage. 246, 101-118 (2019).

10. Basu, M., Guha, A. K. \& Ray, L. Adsorption behavior of cadmium on husk of lentil. Process Saf. Environ. Prot. 106, 11-22 (2017). 
11. Tabatabaeefar, A., Yuan, Q., Salehpour, A. \& Rajabi-Hamane, M. Batch adsorption of lead (II) from aqueous solution onto novel polyoxyethylene sorbitan monooleate/ethyl cellulose microfiber adsorbent: kinetic, isotherm and thermodynamic studies. Sep. Sci. Technol. 55, 1051-1061 (2020).

12. Joseph, L., Jun, B. M., Flora, J. R. V. \& Park, C. M. Removal of heavy metals from water sources in the developing world using low-cost materials: a review. Chemosphere 229, 142-159 (2019).

13. Ariffin, N. et al. Review on adsorption of heavy metal in wastewater by using geopolymer. MATEC Web Conf. 97, 01023 (2017).

14. Burakov, A. E. et al. Adsorption of heavy metals on conventional and nanostructured materials for wastewater treatment purposes: a review. Ecotoxicol. Environ. Saf. 148, 702-712 (2018).

15. Njadshafiee, V. \& Islami, M. N. Adsorption capacity of heavy metal ions using sultone-modified magnetic activated carbon as a bio-adsorbent. Mater. Sci. Eng. C 101, 42-52 (2019).

16. Abuhatab, S., El-Qanni, A., Al-Qalaq, H., Hmoudah, M. \& Al-Zerei. ,. Effective adsorptive removal of Zn2+, Cu2+, and Cr3+ heavy metals from aqueous solutions using silica-based embedded with $\mathrm{NiO}$ and $\mathrm{MgO}$ nanoparticles. J. Environ. Manage. 268, $110713(2020)$.

17. Hong, M. et al. Heavy metal adsorption with zeolites: The role of hierarchical pore architecture. Chem. Eng. J. 359, 363-372 (2019).

18. Wang, Z. et al. Silicaoxide encapsulated natural zeolite for high efficiency removal of low concentration heavy metals in water. Colloids Surf. A Physicochem. Eng. Asp. 561, 388-394389 (2019).

19. Çelebi, H. \& Gök, O. Evaluation of lead adsorption kinetics and isotherms from aqueous solution using natural walnut shell. Int. J. Environ. Res. 11, 83-90 (2017).

20. Benavente, V., Fullana, A. \& Berge, N. D. Life cycle analysis of hydrothermal carbonization of olive mill waste: comparison with current management approaches. J. Clean. Prod. 142, 2637-2648 (2017).

21. Siddiqui, S. H. \& Ahmad, R. Pistachio Shell carbon (PSC) e an agricultural adsorbent for the removal of $\mathrm{Pb}$ (II) from aqueous solution. Groundw. Sustain. Dev. 4, 42-48 (2017).

22. Ghorbani, F., Kamari, S., Zamani, S., Akbari, S. \& Salehi, M. Optimization and modeling of aqueous Cr(VI) adsorption onto activated carbon prepared from sugar beet bagasse agricultural waste by application of response surface methodology. Surf. Interfaces 18, $100444(2020)$.

23. Feizi, M. \& Jalali, M. Removal of heavy metals from aqueous solutions using sunflower, potato, canola and walnut shell residues. J. Taiwan Inst. Chem. Eng. 54, 125-136 (2015).

24. Shen, C. et al. Global profile of heavy metals and semimetals adsorption using drinking water treatment residual. Chem. Eng. J. 372, 1019-1027 (2019).

25. Ong, D. C., Kan, C. C., Pingul-Ong, S. M. B. \& de Luna, M. D. G. Utilization of groundwater treatment plant (GWTP) sludge for nickel removal from aqueous solutions: isotherm and kinetic studies. J. Environ. Chem. Eng. 5, 5746-5753 (2017).

26. Takeno, N. Atlas of Eh-pH diagrams (Intercomparison of thermodynamic databases). Geol. Surv. Jpn. 419, 1-287 (2005).

27. Singh, N. B., Nagpal, G. \& Agrawal, S. Water purification by using adsorbents: a review. Environ. Technol. Innov. 11, 187-240 (2018).

28. Ahmad, T. \& Danish, M. Prospects of banana waste utilization in wastewater treatment: a review. J. Environ. Manag. 206, 330-348 (2018).

29. Yang, S. et al. Mono/competitive adsorption of arsenic(III) and nickel(II) using modified green tea waste. J. Taiwan Inst. Chem. Eng. 60, 213-221 (2016).

30. Hussain, S., Anjali, K. P., Hassan, S. T. \& Dwivedi, P. B. Waste tea as a novel adsorbent: a review. Appl. Water Sci. 8, 165 (2018).

31. Liu, L., Fan, S. \& Li, Y. Removal behavior of methylene blue from aqueous solution by tea waste: kinetics, isotherms and mechanism. Int. J. Environ. Res. Public Health 15, 1321 (2018).

32. Wan, S. et al. Sorption of lead(II), cadmium(II), and copper(II) ions from aqueous solutions using tea waste. Ind. Eng. Chem. Res. 53, 3629-3635 (2014).

33. Khal, H. E. \& Batis, N. H. Effects of temperature on the preparation and characteristics of hydroxyapatite and its adsorptive properties toward lead. New J. Chem. 39, 3597 (2015).

34. Gaya, U. I., Otene, E. \& Abdullah, A. H. Adsorption of aqueous $\mathrm{Cd}(\mathrm{II})$ and $\mathrm{Pb}$ (II) on activated carbon nanopores prepared by chemical activation of doum palm shell. SpringerPlus 4, 458 (2015).

35. Wasewar, K. L., Atif, M., Prasad, B. \& Mishra, I. M. Batch adsorption of zinc on tea factory waste. Desalination 244, 66-71 (2009).

36. Baby, R., Saifullah, B. \& Hussein, M. Z. Palm Kernel Shell as an effective adsorbent for the treatment of heavy metal contaminated water. Sci. Rep. 9, 18955 (2019).

37. Agarwal, R. M., Singh, K., Upadhyaya, S. \& Dohare, R. K. Removal of heavy metals from wastewater using modified agricultural adsorbents. Mater. Today. Proc. 4, 10534-10538 (2017).

38. Thakur, V., Sharma, E., Guleria, A., Sangar, S. \& Singh, K. Modification and management of lignocellulosic waste as an ecofriendly biosorbent for the application of heavy metal ions sorption. Colloid. Surf. B 75, 149-155 (2010).

39. Malakahmad, A., Tan, S. \& Yavari, S. Valorization of wasted black tea as a low-cost adsorbent for nickel and zinc removal from aqueous solution. J. Chem. 2016, 1-8 (2016).

40. Renu, A. M. \& Singh, K. Heavy metal removal from wastewater using various adsorbents: a review. J. Water Reuse Desal. 7, 387-419 (2016).

41. Panneerselvam, P., Morad, N. \& Tan, K. A. Magnetic nanoparticle $\left(\mathrm{Fe}_{3} \mathrm{O}_{4}\right)$ impregnated onto tea waste for the removal of nickel(II) from aqueous solution. J. Hazard. Mater. 186, 160-168 (2011).

42. Jeyaseelan, C. \& Gupta, A. Green tea leaves as a natural adsorbent for the removal of $\mathrm{Cr}(\mathrm{VI})$ from aqueous solutions. Air Soil Water Res. 9, 13-19 (2016).

43. Yusof, M. S. M. et al. Arsenic adsorption mechanism on palm oil fuel ash (POFA) powder suspension. J. Hazard. Mater. 383, $121214(2020)$

44. Draman, S. F. S. et al. Adsorption of lead (II) ions in aqueous solution using selected agro-waste. ARPN J. Eng. Appl. Sci. 10, 297-300 (2015).

45. Ghasemi, S., Gholami, R. M. \& Yazdanian, M. Biosorption of heavy metal from cadmium rich aqueous solutions by tea waste as a low cost bio-adsorbent. Jundishapur J. Health Sci. 9, e37301 (2017).

46. Weng, C. et al. Effective removal of copper ions from aqueous solution using base treated black tea waste. Ecol. Eng. 67, 127-133 (2014).

47. Batool, F., Akbar, J., Iqbal, S., Noreen, S. \& Bukhari, S. N. A. Study of isothermal, kinetic, and thermodynamic parameters for adsorption of cadmium: an overview of linear and nonlinear approach and error analysis. Bioinorg. Chem. Appl. 2018, 1-11 (2018).

48. Subramanyam, B. \& Das, A. Linearised and non-linearised isotherm models optimization analysis by error functions and statistical means. J. Environ. Health Sci. Eng. 12, 92 (2014).

49. Lee, S. Y. \& Choi, H. J. Persimmon leaf bio-waste for adsorptive removal of heavy metals from aqueous solution. J. Environ. Manage. 209, 382-392 (2018).

50. Shafiq, M., Alazba, A. A. \& Amin, M. T. Removal of heavy metals from wastewater using date palm as a biosorbent: a comparative review. Sains Malaysiana 47, 35-49 (2018).

51. Mayacela Rojas, C. M., Rivera Velásquez, M. F., Tavolaro, A., Molinari, A. \& Fallico, C. Use of vegetable fibers for PRB to remove heavy metals from contaminated aquifers-comparisons among cabuya fibers, broom fibers and ZVI. Int. J. Environ. Res. Public Health 14, 684 (2017). 
52. Futalan, C. M., Kim, J. \& Yee, J. J. Adsorptive treatment via simultaneous removal of copper, lead and zinc from soil washing wastewater using spent coffee grounds. Water Sci. Technol. 79, 1029-1041 (2019).

53. ASTM. American Standard of Testing Material, Standard Test Method for Total Ash Content of Activated Carbon ASTM D2866-94 (2004).

54. ASTM. American Standard of Testing Material. Standard Test Method for Moisture in Activate Carbon ASTM D 2867-95 (1996).

55. Hall, K. R., Eagleton, L. C., Acrivos, A. \& Vermeulen, T. Pore-and solid-diffusion kinetics in fixed-bed adsorption under constantpattern conditions. Ind. Eng. Chem. Fundam. 5, 587-594 (1966).

56. Dubinin, M. M. \& Radushkevich, L. V. Equation of the characteristic curve of activated charcoal. Proc. Acad. Sci. Phys. Chem. Sect. 55, 331-337 (1947).

57. Temkin, M. \& Pyzhev, V. Recent modifications to langmuir isotherms. Acta Physicochim. USSR 12, 217-225 (1940).

58. Langmuir, I. The constitution and fundamental properties of solids and liquids. Part-II-liquids. J. Am. Chem. Soc. 38, 102-105 (1916).

59. Freundlich, H. Über die adsorption in lösungen: Zeitschrift für Physikalische Chemie. J. Am. Chem. Soc. 62, 121-125 (1906).

60. Ho, Y. S. \& Mckay, G. Pseudo-second order model for sorption processes. Process Biochem. 34, 451-465 (1999).

\section{Acknowledgements}

This study was carried out at Aksaray University, Faculty of Engineering, Environmental Engineering Department. I am thankful for all the academic supports ensured by the editors and reviewers of the Scientific Reports.

\section{Author contributions}

H.Ç. conceived the experiment(s), H.Ç., G.G. and O.G. conducted the experiment(s), H.Ç., G.G. and O.G analyzed the results. All authors reviewed the manuscript.

\section{Competing interests}

The authors declare no competing interests.

\section{Additional information}

Supplementary information is available for this paper at https://doi.org/10.1038/s41598-020-74553-4.

Correspondence and requests for materials should be addressed to H.Ç.

Reprints and permissions information is available at www.nature.com/reprints.

Publisher's note Springer Nature remains neutral with regard to jurisdictional claims in published maps and institutional affiliations.

Open Access This article is licensed under a Creative Commons Attribution 4.0 International License, which permits use, sharing, adaptation, distribution and reproduction in any medium or format, as long as you give appropriate credit to the original author(s) and the source, provide a link to the Creative Commons licence, and indicate if changes were made. The images or other third party material in this article are included in the article's Creative Commons licence, unless indicated otherwise in a credit line to the material. If material is not included in the article's Creative Commons licence and your intended use is not permitted by statutory regulation or exceeds the permitted use, you will need to obtain permission directly from the copyright holder. To view a copy of this licence, visit http://creativecommons.org/licenses/by/4.0/.

(c) The Author(s) 2020 